OPEN ACCESS

Edited by:

Edna Grünblatt,

University of Zurich, Switzerland

Reviewed by:

Markus P. Kummer,

University of Bonn, Germany

Kempuraj Duraisamy,

University of Missouri, USA

*Correspondence: Byeong C. Kim

byeong.kim7@gmail.com

Received: 22 December 2016 Accepted: 23 February 2017 Published: 07 March 2017

Citation:

Song J, Choi S-M and Kim BC (2017) Adiponectin Regulates the Polarization and Function of Microglia

via PPAR- $\gamma$ Signaling Under Amyloid $\beta$ Toxicity.

Front. Cell. Neurosci. 11:64. doi: 10.3389/fncel.2017.00064

\section{Adiponectin Regulates the Polarization and Function of Microglia via PPAR- $\gamma$ Signaling Under Amyloid $\beta$ Toxicity}

\author{
Juhyun Song ${ }^{1}$, Seong-Min $\mathrm{Choi}^{2}$ and Byeong C. Kim ${ }^{2 *}$ \\ 'Department of Biomedical Sciences, Center for Creative Biomedical Scientists at Chonnam National University, Gwangju, \\ South Korea, ${ }^{2}$ Department of Neurology, Chonnam National University Medical School, Gwangju, South Korea
}

Alzheimer's disease (AD), characterized by the abnormal accumulation of amyloid beta $(A \beta)$, is gradually increasing globally. Given that $A D$ is considered a neuroinflammatory disease, recent studies have focused on the cellular mechanisms in brain inflammatory conditions that underlie AD neuropathology. Microglia are macrophage cells in the central nervous system (CNS) that are activated in response to $A \beta$ condition. The function of microglia contributes to the neuroinflammation in AD brain, suggesting that microglia regulate the production of inflammatory mediators and contribute to the regeneration of damaged tissues. Adiponectin, an adipokine derived from adipose tissue, has been known to regulate inflammation and control macrophages during oxidative stress conditions. In present study, we investigated whether adiponectin influences the polarization and function of microglia under $A \beta$ toxicity by examining alterations of BV2 microglia function and polarization by Acrp30 (a globular form of adiponectin) treatment using reverse transcription PCR, western blotting and immunofluorescence staining. Acrp30 promoted the induction of the M2 phenotype, and regulated the inflammatory responses through peroxisome proliferator-activated receptor (PPAR) $-\gamma$ signaling under $A \beta$ toxicity. In addition, Acrp30 boosted the capacity of $A \beta$ scavenging in microglia. Taken together, we suggest that adiponectin may control the function of microglia by promoting anti-inflammatory responses through PPAR$\gamma$ signaling. Hence, we conclude that adiponectin may act as a critical controller of microglia function in the AD brain.

\footnotetext{
Keywords: adiponectin, Acrp30, microglia, inflammation, amyloid beta (A $\beta$ ), cytokines, peroxisome proliferatoractivated receptor (PPAR)- $\gamma$
}

\section{INTRODUCTION}

Alzheimer's disease (AD) is the most common cause of dementia, manifesting as memory decline and cognitive dysfunction (Bubu et al., 2016; De Strooper and Karran, 2016; Tarantini et al., 2016). $\mathrm{AD}$ is defined by two pathological characteristics: amyloid $\beta$-protein $(\mathrm{A} \beta)$ deposition in senile plaques and phosphorylated tau in neurofibrillary tangles (Goate, 2006). Excessive accumulation of $A \beta$ has been shown to lead to the cognitive impairments in $A D$ 
(Hardy and Selkoe, 2002; Hardy et al., 2014), and has been shown to trigger inflammation (Del Bo et al., 1995; Combs et al., 2001; Takata et al., 2003; Lindberg et al., 2005; Kempuraj et al., 2016; Stamouli and Politis, 2016) through the production of cytokines and other inflammatory mediators. Several studies of AD brains reported the presence of activated glial cells around the $\mathrm{A} \beta$ plaques (Mehlhorn et al., 2000; Rogers and Lue, 2001); (uroff, 2017 \#365). Microglia, the resident macrophages of the central nervous system (CNS; Nakamichi et al., 2013; Ginhoux and Prinz, 2015), constitute $10 \%-15 \%$ of brain cells and play a critical role in CNS homeostasis (Solé-Domènech et al., 2016). Previous studies demonstrated that microglia polarizes into two states, M1 like phenotype and M2 like phenotypes (Francos-Quijorna et al., 2016; Lee et al., 2016). M1 like phenotype microglia is related with pro inflammatory response's induction, whereas M2 like phenotype microglia is associated with neuroprotective roles (Eggen et al., 2013; Gertig and Hanisch, 2014; Natoli and Monticelli, 2014; Plastira et al., 2016; Xu et al., 2016). The polarization of microglia is important in CNS homeostasis as it has been shown to affect learning and memory (Tremblay et al., 2011, 2015; Parkhurst et al., 2013). Numerous studies have suggested that microglia are activated in the $\mathrm{AD}$ brain and contribute to the prevention of $A \beta$ formation through phagocytosis of $\mathrm{A} \beta$ (Rogers et al., 2002; Doens and Fernández, 2014). Several studies have demonstrated that M2 type microglia reduce inflammation in the brain (Weekman et al., 2014; Latta et al., 2015) and ameliorate cognitive dysfunction during $A \beta$ toxicity (Zhu et al., 2016). These data highlight the necessity to elucidate the mechanisms underlying $A \beta$ clearance by microglia, thereby attenuating $\mathrm{AD}$ progression. Adiponectin is encoded by the ADIPOQ gene (Maeda et al., 1996) and exerts multiple effects by binding to two specific receptors, AdipoR1 and AdipoR2 (Yamauchi et al., 2003; Hug et al., 2004). Adiponectin receptors exist in various organs, including the liver and brain (Kim et al., 2013; Kaminski et al., 2014). Previous researches have demonstrated that adiponectin acts as an insulin sensitizer, an anti-inflammatory regulator and an anti-atherosclerotic molecule (Kadowaki et al., 2006; Renaldi et al., 2009). Recent research has focused on the effect of adiponectin on macrophages (Elfeky et al., 2016; Masamoto et al., 2016; Wang et al., 2016); specifically, that adiponectin may not only act as a key regulator of inflammatory response in metabolic diseases, but also in CNS diseases (Wang et al., 2016). In the present study, we investigate whether adiponectin contributes to the polarization and the scavenger capacity of microglia under $A \beta$ toxicity. The results provide significant evidence for the therapeutic potential of adiponectin to mitigate $\mathrm{AD}$ pathology by regulating the function of microglia.

\section{MATERIALS AND METHODS}

\section{Animal Experiments}

$5 x F A D$ male transgenic mice ( 5 months of age) with detectable $\mathrm{A} \beta_{42}$ production in the brain were purchased from The Jackson Laboratory (Bar Harbor, ME). Wild-type male C57BL/6 mice (25 g, 5 months of age) were provided by Koatech (Koatech, Pyeongtaek, South Korea). In the present study, we used four mice in each groups. This study was carried out in accordance with the recommendations of "96 Guidance for Animal Experiments", established by the "Animal Ethics Committee" at Chonnam National University. The protocol was approved by the "Animal Ethics Committee" at Chonnam National University, approved study number 2016-84. The animals were housed in an airconditioned room at $25^{\circ} \mathrm{C}$ with a $12 \mathrm{~h}$ dark/light cycle. All animals received human care with unlimited access to chow and water.

\section{Cell Culture and Drug Treatment}

Murine BV2 microglial cells were cultured in Dulbecco Modified Eagle Medium (DMEM; Gibco, Grand Island, NY, USA) supplemented with $10 \%$ fetal bovine serum (Gibco), $100 \mu \mathrm{g} / \mathrm{ml}$ penicillin (Gibco) and $100 \mu \mathrm{g} / \mathrm{ml}$ streptomycin (Gibco). BV2 cells were grown in a humidified incubator at $37^{\circ} \mathrm{C}$ with $5 \% \quad \mathrm{CO}_{2}$. The cells were pretreated with Acrp30 (5 $\mu \mathrm{g} / \mathrm{ml}$; Sigma-Aldrich, St. Louis, MO, USA) for $24 \mathrm{~h}$ and then treated with $\mathrm{A} \beta(10 \mu \mathrm{M})$ for $24 \mathrm{~h}$. GW9662 was used as the antagonist for PPAR- $\gamma$ (Chen et al., 2016). BV2 cells were pretreated with GW9662 $(10 \mu \mathrm{M})$ for $3 \mathrm{~h}$.

\section{A $\beta$ Oligomer Preparation}

Oligomeric $\mathrm{A} \beta$ was prepared as previously described (An et al., 2013). One milligram of synthetic A $\beta 42$ peptide (American Peptide, Sunnyvale, CA, USA) was dissolved into $1 \mathrm{ml}$ HFIP (1,1,1,3,3,3-hexafluoro-2-propanol). The solution should then be dried under a nitrogen stream. Re-dissolved the remaining film in $100 \%$ HFIP to a concentration of $1 \mathrm{mg} / \mathrm{ml}$. Sonicated in bath sonicator for $5 \mathrm{~min}$ and dried under a nitrogen stream. Repeated the HFIP treatment twice. Then re-dissolved in $1 \mathrm{ml}$ HFIP and dried for $2 \mathrm{~h}$. After that the film was resuspended in 200 ul DMSO to obtain a $1 \mathrm{mM} \mathrm{A} \beta$ stock solution. For $10 \mu \mathrm{M} \mathrm{A} \beta 42$ treatment, 10 ul of $\mathrm{A} \beta 421 \mathrm{mM}$ was dilute into $10 \mathrm{ml}$ DMEM cell culture media and incubated for $12 \mathrm{~h}$ at $37^{\circ} \mathrm{C}$.

\section{Preparation of the AdipoR1 and AdipoR2 Targeting siRNA}

The siRNA for AdipoR1 and AdipoR2 (5 $\mu \mathrm{M})$ was prepared to silence AdipoR1 siRNA sc-60123 (Santa Cruz Biotechnology, Santa Cruz, CA, USA) and AdipoR2 siRNA sc-46756 (Santa Cruz Biotechnology). For the transfection of siRNA, a $5 \mu \mathrm{M}$ final concentration of siRNA AdipoR1 and siRNA AdipoR2 were combined with lipofectamine 2000 (Invitrogen, Carlsbad, CA, USA) in Opti-MEM medium, and incubated at room temperature for $20 \mathrm{~min}$. The mixture was added to the BV 2 cells in six well plates. After 2 days, the cells were collected for total protein or RNA extraction.

\section{Determination of Nitrite}

BV2 microglia were seeded onto 96-well plates and pre-treated with Acrp30 $(5 \mu \mathrm{g} / \mathrm{ml})$ for $24 \mathrm{~h}$ prior to stimulation with $10 \mu \mathrm{M}$ of $A \beta$. Supernatants in all groups were measured by nitric oxide 
(NO) production using Griess reagent (Sigma-Aldrich). The reagents $(100 \mu \mathrm{l})$ were added to the plate and incubated for $30 \mathrm{~min}$. The absorbance of supernatants was measured at $540 \mathrm{~nm}$ using an ELISA reader (Bio-Rad, Irvine, CA, USA).

\section{ELISA Assay}

BV2 cells were plated in 6 -well plates $\left(5 \times 10^{5}\right.$ cells $\left./ \mathrm{ml}\right)$ and incubated with Acrp30 $(5 \mu \mathrm{g} / \mathrm{ml})$ in the presence of $\mathrm{A} \beta 10 \mu \mathrm{M}$ for $24 \mathrm{~h}$. The production of TNF- $\alpha$ was checked by Cymax Mouse TNF- $\alpha$ ELISA kit (AbFrontier, Seoul, Korea) per manufacturer's instructions. The absorbance at $450 \mathrm{~nm}$ was assessed by ELISA (Bio-Rad).

\section{Phagocytosis Assay}

The phagocytosis assay was conducted using the Cayman chemical phagocytosis kit (Cayman Chemical, Ann Arbor, MI, USA). To check opsonization of target particles, all phagocytosis assays were conducted in complete DMEM media. Additionally, in some experiments, labeled particles were preopsonized by incubation at $37^{\circ} \mathrm{C}$ for $3 \mathrm{~h}$ with $5 \mathrm{mg} / \mathrm{mL}$ immunoglobulin $\mathrm{G}$ (IgG; Beletskii et al., 2005; Cayman Chemical).

\section{Western Blot Analysis}

The BV2 cells were washed with phosphate-buffered saline (PBS) and collected. Cell pellets were lysed with ice-cold RIPA buffer (Sigma-Aldrich). The lysates were centrifuged at 15,900 $\mathrm{g}$ for $30 \mathrm{~min}$ at $4^{\circ} \mathrm{C}$ to produce whole-cell extracts. Protein $(30 \mu \mathrm{g})$ in cells was separated on a $10 \%$ SDS-polyacrylamide gel and transferred onto a polyvinylidene difluoride membrane. After blocking with $5 \%$ skim milk prepared in Tris-buffered salineTween (20 nM Tris [pH 7.2], $150 \mathrm{mM} \mathrm{NaCl}, 0.1 \%$ Tween 20) for $1 \mathrm{~h}, 30 \mathrm{~min}$ at room temperature, immunoblots were incubated for $18 \mathrm{~h}$ at $4^{\circ} \mathrm{C}$ with primary antibodies that detect AdipoR1 (1:1000, Abcam, Cambridge, MA, USA), AdipoR2 (1:1000, Abcam, Cambridge, MA, USA), CD86 (1:1000, Cell Signaling, Danvers, MA, USA), p-NF-кB (1:1000, Cell Signaling), PPAR- $\gamma$ (1:1000, Cell Signaling, Danvers, MA), p-PPAR- $\gamma$ (1:1000, Santa Cruz Biotechnology, Santa Cruz, CA, USA) and $\beta$-actin (1:1000; Millipore, Billerica, MA, USA). All blots were then incubated with appropriate secondary antibodies (Abcam, Cambridge, MA, USA) for $1 \mathrm{~h} 30 \mathrm{~min}$ at room temperature. All blots were visualized using ECL solution (Millipore, Billerica, MA, USA).

\section{Quantitative Real-Time PCR}

To examine the amount of CD86, CD206, iNOS and TNF- $\alpha$ mRNA in BV2 cells, quantitative real-time PCR was performed using each primer. Cellular RNA was extracted from BV2 cells using Trizol reagent (Invitrogen). RNA was mixed with One Step SYBR ${ }^{\circledR}$ Prime Script TM RT-PCR Kit II (Takara, Otsu, Shiga, Japan) and specific primers in a total reaction volume of $50 \mu \mathrm{l}$. PCR was performed using the following each primers $\left(5^{\prime}\right.$ to $3^{\prime}$ ): CD86 (F): GTA TTT TGG CAG GAC CAG GA, (R): GCC GCT TCT TCT TCT TCC AT, CD206 (F): GAG GGA AGC GAG AGA TTA TGG A, (R): GCC TGA TGC CAG GTT AAA GCA, iNOS (F): GGG AAT CTT GGA GCG AGT TG, (R): GTG AGG GCT TGG CTG AGT GA, TNF- $\alpha$ (F): CGT CAG CCG

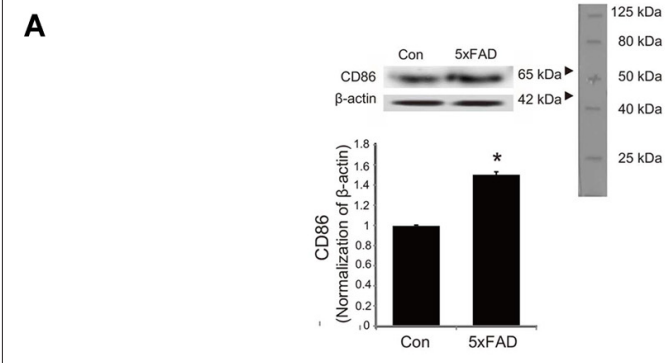

B

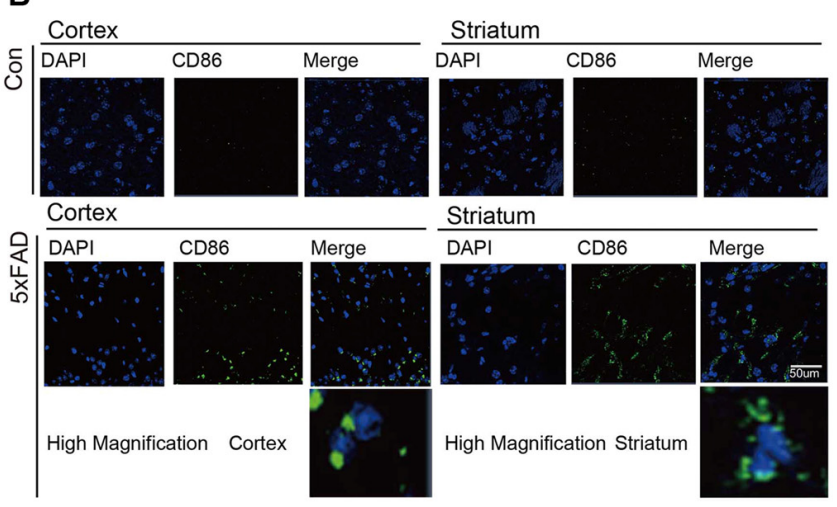

C

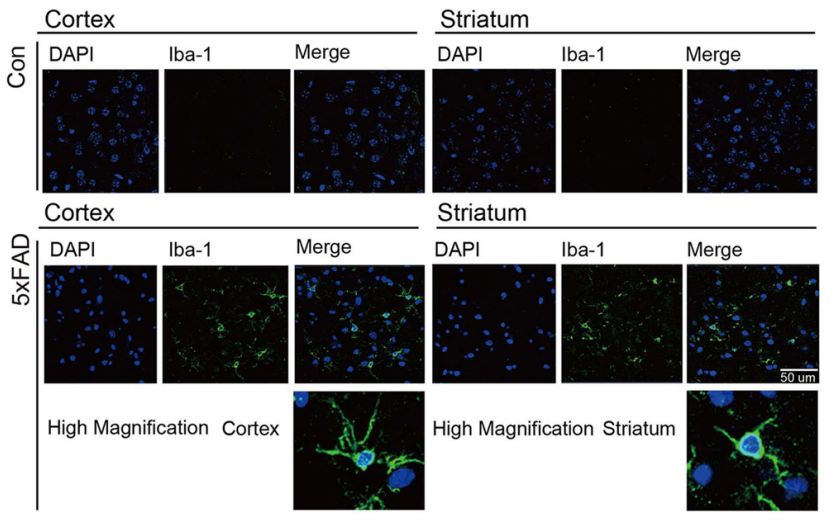

FIGURE 1 | The expression of CD86 and Iba-1 in 5xFAD mouse brain. (A) Western blotting band showed increased CD86 protein level in the 5xFAD mouse brain. Data are expressed as mean \pm SEM. Each experiment was conducted three times per condition. $\beta$-actin served as a control. Differences were considered statistically significant at ${ }^{*} p<0.05$ (compared to control). Immunofluorescence images showed increased expression of CD86 (B) and Iba-1 (C) in the cortex and striatum of the 5xFAD mouse brain. Scale bar: $50 \mu \mathrm{m}$, Con: normal mouse, 5xFAD: 5xFAD mouse, CD86: green, Iba-1: green, 4',6-diamidino-2-phenylindole (DAPI): blue.

ATT TGC TAT CT, (R): CGG ACT CCG CAA AGT CTA AG, GAPDH (F): GAC AAG CTT CCC GTT CTC AG, (R): GAG TCA ACG GAT TTG GTC GT. Amplification cycles were carried out at $52^{\circ} \mathrm{C}$ for $5 \mathrm{~min}, 95^{\circ} \mathrm{C}$ for $10 \mathrm{~s}, 95^{\circ} \mathrm{C}$ for $5 \mathrm{~s}, 58^{\circ} \mathrm{C}$ for $35 \mathrm{~s}$ and $65^{\circ} \mathrm{C}$ for $15 \mathrm{~s}$. Quantitative SYBR Green real time PCR was performed with Takara PCR System (Takara, Otsu, Shiga, Japan). GAPDH was used as an internal control. The $\Delta \mathrm{Ct}$ values of treated cells were compared to those of normal, control cells (Popivanova et al., 2008). 

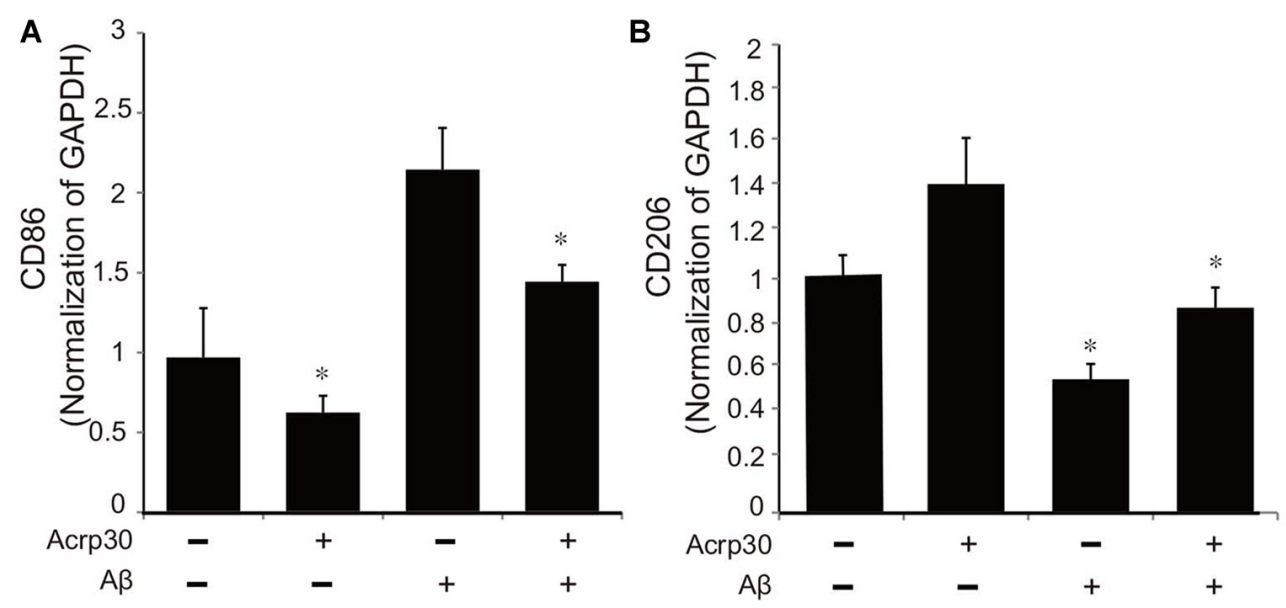

C
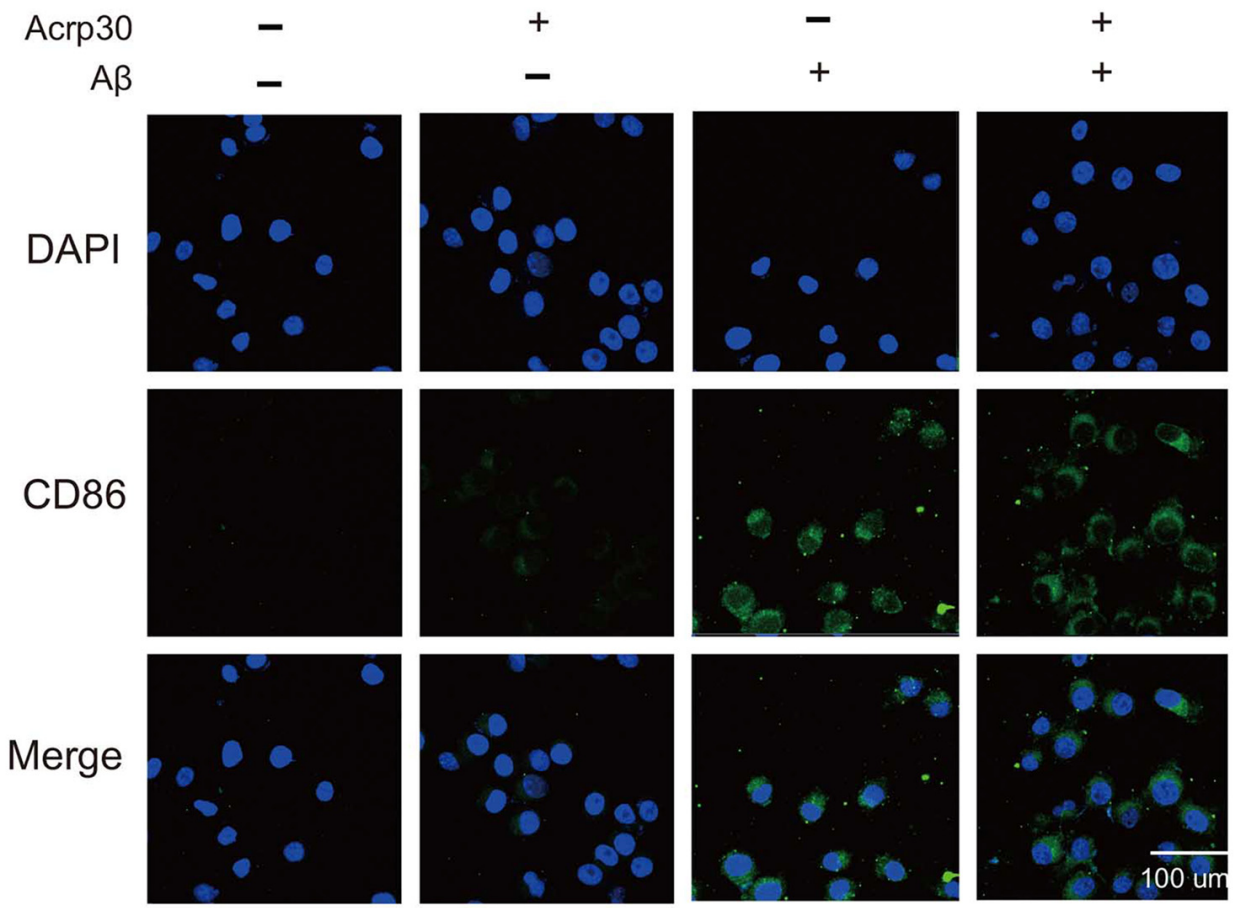

FIGURE 2 | The expression of CD86 and CD206 in amyloid beta (A $\mathbf{\beta}$ )-treated BV2 microglia. The mRNA level of CD86 (A) and CD206 (B) was detected by RT PCR. Data are expressed as mean \pm SEM. Each experiment was conducted three times per condition. GAPDH served as a control. Differences were considered statistically significant at ${ }^{*} p<0.05$ (compared to control). (C) Immunofluorescence images showed the reduction of CD86 by Acrp30 pretreatment in A $\beta$ - exposed BV2 microglia. Acrp30: Acrp30 $5 \mu \mathrm{g} / \mathrm{ml}$ pretreatment, A $\beta$ : A $10 \mu \mathrm{M}$ treatment for $24 \mathrm{~h}$, Scale bar: $100 \mu \mathrm{m}, \mathrm{CD} 86$ : green, 4',6-diamidino-2-phenylindole (DAPI): blue.

\section{Reverse Transcription PCR}

Total RNA in BV2 cells was isolated using Trizol Reagent (Gibco). RT-PCR reaction was conducted by using the Invitrogen One step III ${ }^{\mathrm{TM}}$ Reverse Transcription PCR kit (Invitrogen). cDNA synthesis from mRNA and sample normalization were conducted. PCR was performed using the following thermal cycling conditions: $95^{\circ} \mathrm{C}$ for $10 \mathrm{~min}$; 40 cycles of denaturing at $95^{\circ} \mathrm{C}$ for $15 \mathrm{~s}$, annealing at $60^{\circ} \mathrm{C}$ for $30 \mathrm{~s}$, elongation at $72^{\circ} \mathrm{C}$ for $30 \mathrm{~s}$, final extension at $72^{\circ} \mathrm{C}$ for $5 \mathrm{~min}$ and holding at $4^{\circ} \mathrm{C}$. PCR was performed using the following primers (5' to $\left.3^{\prime}\right)$ : AdipoR1 (F): CCCACCATGCACTTTACTAT, (R) CACCATAGAAGTGGACGAAA, AdipoR2 (F): CAACC TTGCTTCATCTACCT, (R): CTAGCCATAAGCATTAGCCA, CD36 (F): GAG CCA TCT TTG AGC CTT CA, (R): TCA GAT CCG AAC ACA GCG TA, PPAR- $\gamma$ (F): CAA TCC GAA TTT TTC AAG GGT GCC A, (R): GAG CAC CTT GGC GAA CAG CTG AGA G, iNOS (F): GGG AAT CTT GGA GCG AGT TG, (R): GTG AGG GCT TGG CTG AGT GA, TNF- $\alpha$ (F): CGT 

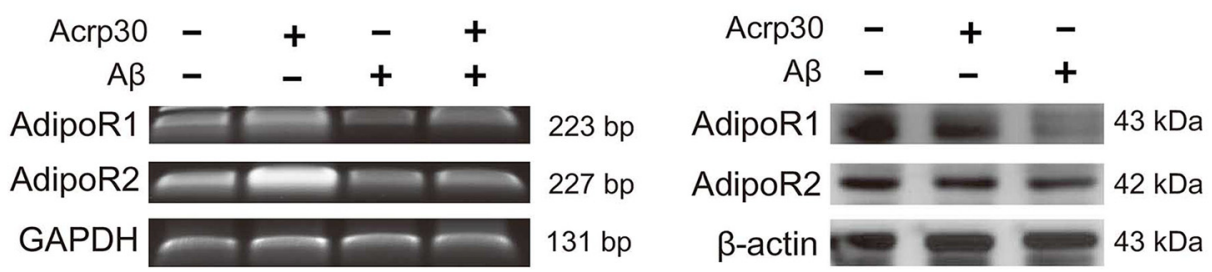

A

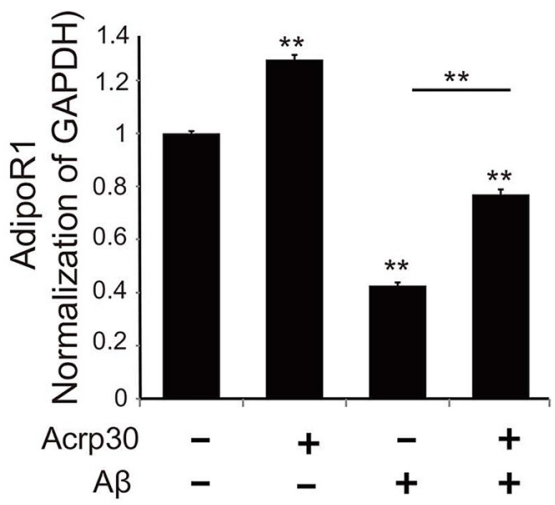

B

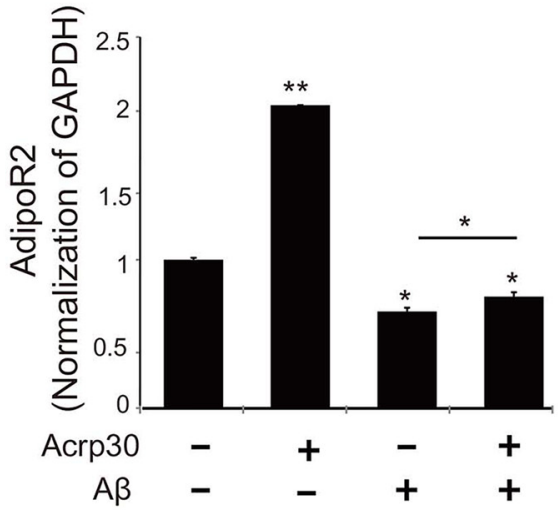

C

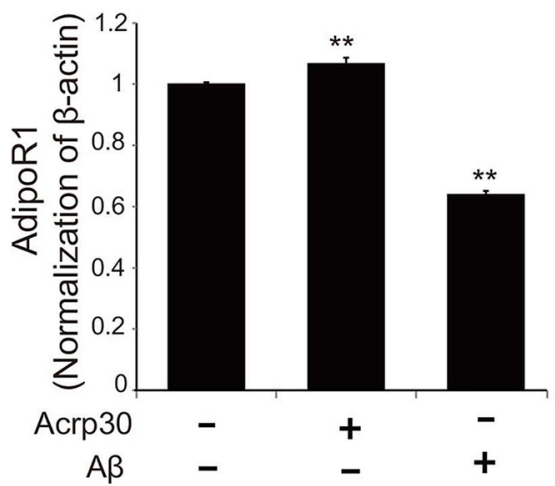

D

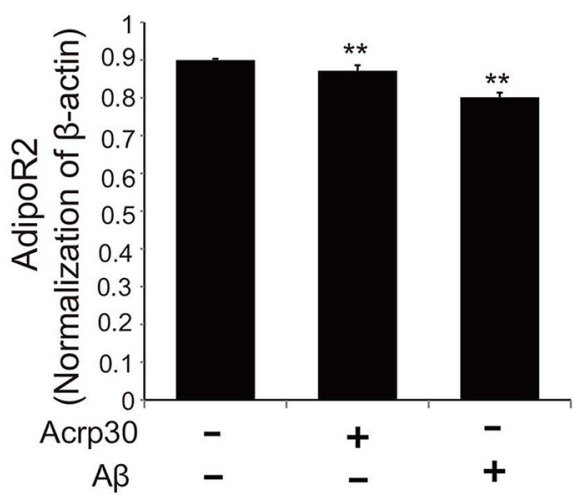

FIGURE 3 | The expression of adiponectin receptors in BV2 microglia. The mRNA levels of AdipoR1 (A) and AdipoR2 (B) were measured by RT-PCR. The protein levels of AdipoR1 (C) and AdipoR2 (D) were detected by western blotting analysis. Data are expressed as mean \pm SEM. Each experiment was conducted three times per condition. $\beta$ - actin served as a control. Differences were considered statistically significant at ${ }^{*} p<0.05$, ${ }^{* *} p<0.001$ (compared to control). Acrp30: Acrp30 $5 \mu \mathrm{g} / \mathrm{ml}$ pretreatment, $A \beta$ : $A \beta 10 \mu \mathrm{M}$ treatment for $24 \mathrm{~h}$.

CAG CCG ATT TGC TAT CT, (R): CGG ACT CCG CAA AGT CTA AG, GAPDH (F): GAC AAG CTT CCC GTT CTC AG, (R): GAG TCA ACG GAT TTG GTC GT. PCR products were electrophoresed in $1 \%$ agarose gels. All samples were normalized with GAPDH.

\section{Immunocytochemistry}

BV2 cells were washed with PBS and permeabilized for $20 \mathrm{~min}$ with $4 \%$ paraformaldehyde (Sigma-Aldrich). The cells were incubated with the primary antibodies overnight at $4^{\circ} \mathrm{C}$. The primary antibody anti-rabbit CD86 (1:500, Cell Signaling) as a marker of M1 phenotype microglia (Gong et al., 2016) was used. After incubation, BV2 cells were washed twice with PBS and incubated with specific secondary antibody for $1 \mathrm{~h} 30 \mathrm{~min}$ at room temperature. The cells were counterstained with $1 \mu \mathrm{g} / \mathrm{ml}$ 4',6-diamidino-2-phenylindole (DAPI, 1:100, Invitrogen) for $10 \mathrm{~min}$ at room temperature. Images were obtained using an LSM 520 confocal microscope (Carl Zeiss, Thornwood, NY, USA).

\section{Immunohistochemistry}

Brain sections $(20 \mu \mathrm{m})$ were mounted onto coated glass slides (Thermo Scientific, Waltham, MA, USA), and fixed in cold 
A

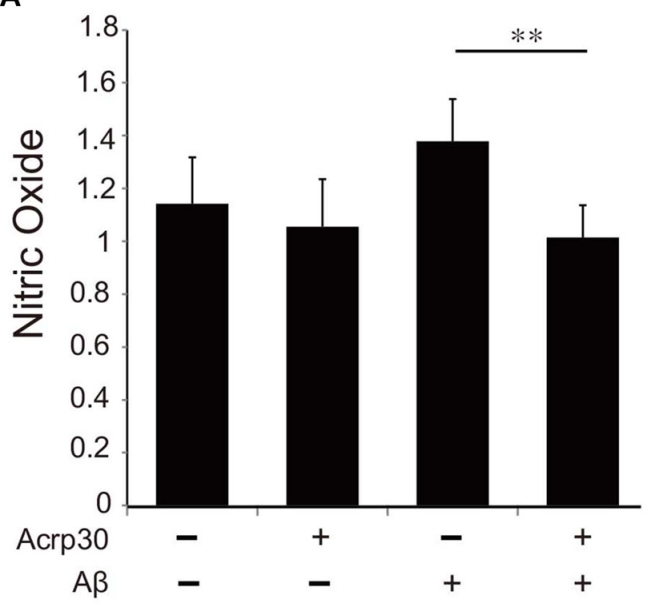

C

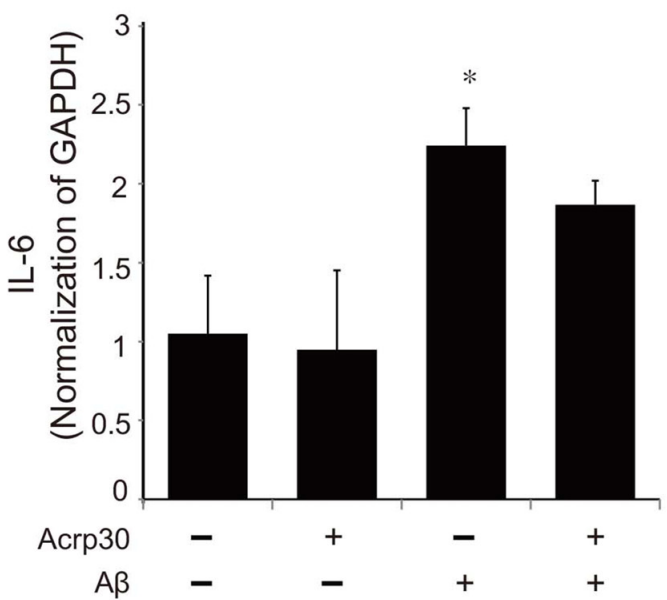

B

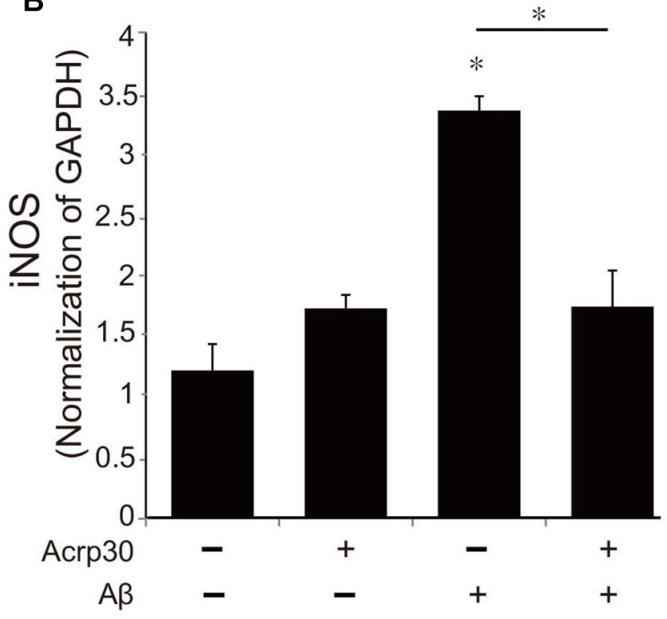

D

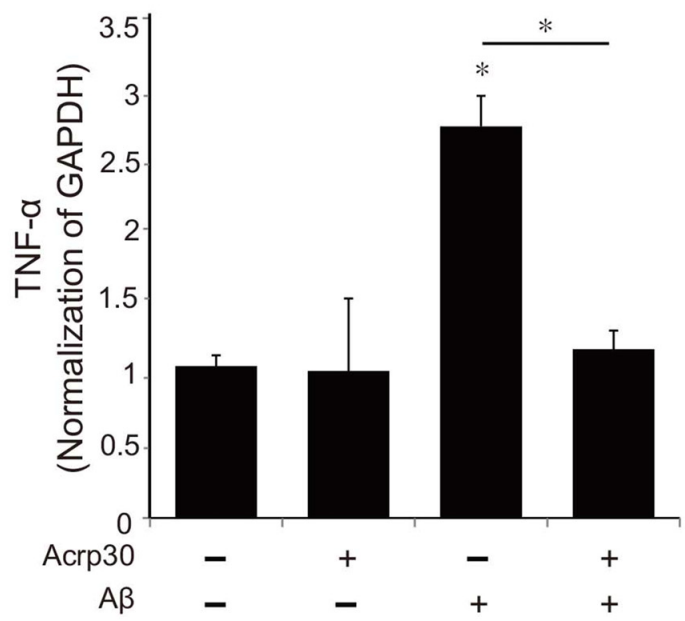

FIGURE 4 | The expression of pro-inflammatory mediators in A $\beta$-treated BV2 microglia. (A) The production of nitric oxide (NO) was assessed by Griess reagent assay. Acrp30 reduced the production of NO in A $\beta$-treated microglia. The increased mRNA level of iNOS (B) and IL-6 (C) and TNF- $\alpha$ (D) were measured by RT PCR. Data are expressed as mean \pm SEM. Each experiment was conducted four times per condition. GAPDH served as a control. Differences were considered statistically significant at ${ }^{*} p<0.05 .{ }^{* *} p<0.001$ (compared to control). Acrp30: Acrp30 $5 \mu \mathrm{g} / \mathrm{ml}$ pretreatment, AB: A $10 \mu \mathrm{M}$ treatment for $24 \mathrm{~h}$.

acetone for $10 \mathrm{~min}$ at $-20^{\circ} \mathrm{C}$. The slides were washed in Tris-buffered saline and incubated with $0.3 \% \mathrm{H}_{2} \mathrm{O}_{2}$ in methanol. To block nonspecific labeling, sections were incubated in 5\% bovine serum albumin (Sigma-Aldrich) and diluted in PBS for $80 \mathrm{~min}$ before the addition of primary and secondary antibody. Primary antibodies for anti-rabbit CD86 (1:100, Cell Signaling) and anti-rabbit Iba-1 (1:100, Cell Signaling) were applied to the samples overnight at $4^{\circ} \mathrm{C}$, followed by $1 \mathrm{~h} 30 \mathrm{~min}$ incubation with appropriate florescence secondary antibody (1:100, Millipore), and three washes in PBS for 5 min each. After three washes in $0.1 \%$ PBS with Tween-20 (PBST), the sections were incubated with secondary antibody for $1 \mathrm{~h} 30 \mathrm{~min}$ in the dark at room temperature. After three washes in PBS, all sections were incubated with $1 \mu \mathrm{g} / \mathrm{ml}$ DAPI (Sigma-Aldrich, St. Louis, MO, USA) and visualized under a LSM 520 confocal microscope (Carl Zeiss).

\section{Statistical Analysis}

The data were analyzed by SPSS 18.0 software (IBM Corp., Armonk, NY, USA). All results are expressed as mean \pm standard deviation (SD). Statistical significance was determined using one-way analysis of variance (ANOVA) followed by Turkey's multiple comparison and Student's $t$-test. Differences were considered statistically significant at $p<0.05$.

\section{RESULTS}

\section{The Activation and Polarization of Microglia in AD Mouse Brain}

To confirm the activation of microglia in the mouse brain, we detected the protein level of CD86 as a marker of activated microglia using western blot (Figure 1A), and the expression of CD86 and Iba-1 using immunohistochemistry 

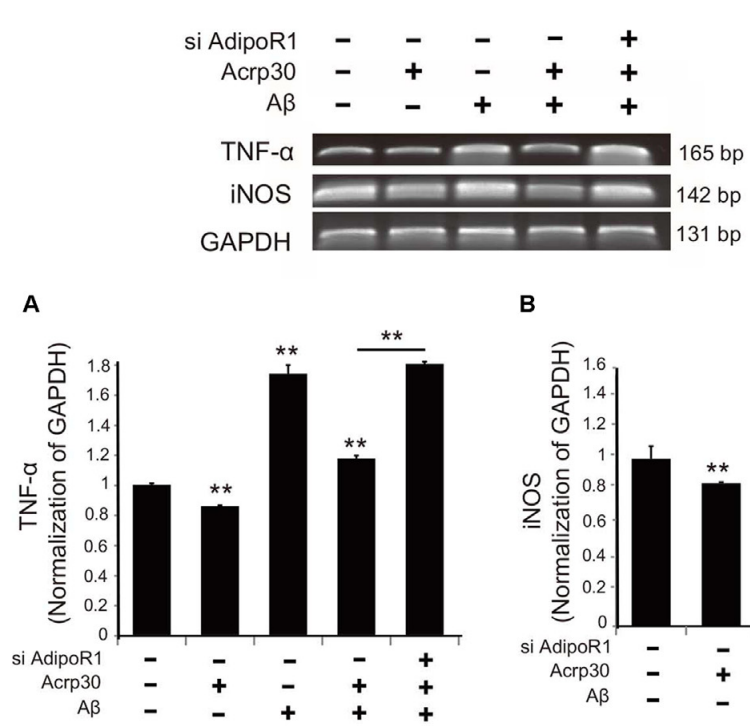

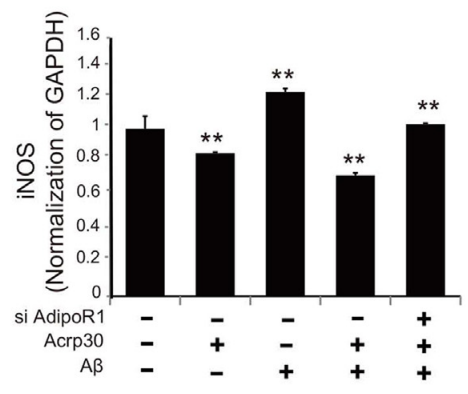

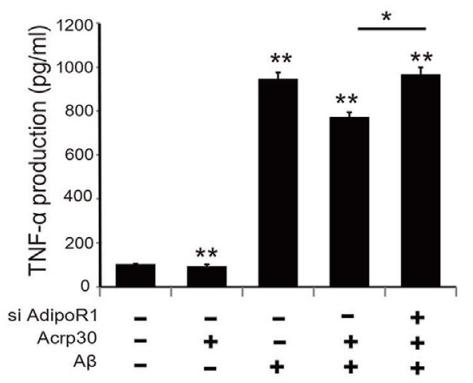

FIGURE 5 | The expression of pro-inflammatory mediators by suppressing AdipoR1 in A $\boldsymbol{\beta}$-treated BV2 microglia. The reduced mRNA level of TNF- $\alpha$ (A) and iNOS (B) and TNF- $\alpha$ (C) in A $\beta$-treated microglia were assessed by RT PCR. (C) The reduced production of TNF- $\alpha$ by Acrp30 in A $\beta$-treated microglia was increased by blocking AdipoR1. Data are expressed as mean \pm SEM. Each experiment was conducted four times per condition. GAPDH served as a control. Differences were considered statistically significant at ${ }^{*} p<0.05 .{ }^{* *} p<0.001$ (compared to control). Acrp30: Acrp30 $5 \mu \mathrm{g} / \mathrm{ml}$ pretreatment, A $\beta$ : A $\beta$ 10 $\mu \mathrm{M}$ treatment for $24 \mathrm{~h}$.

(Figures 1B,C). Our data showed higher activation of microglia (increased CD86 protein level and a greater percentage of CD86 and Iba-1 positive cells) in the $\mathrm{AD}$ compared to the control mouse brain (Figures 1A-C). These results suggest that microglia are activated in an $\mathrm{AD}$ brain with $\mathrm{A} \beta$ accumulation. To assess the polarization of microglia with $\mathrm{A} \beta$ treatment and Acrp30 (a globular form of adiponectin) pretreatment, we assessed the mRNA level of CD86 as a marker of M1 phenotype microglia and of CD206 as a marker of M2 phenotype microglia (Figure 2). The mRNA level of CD206 was reduced while the mRNA level of CD86 was markedly increased in $A \beta$-exposed microglia (Figures 2A,B). Acrp30 reduced the expression of CD86 and increased the expression of CD206 in BV2 microglia (Figures 2A,B). Furthermore, Acrp30 pretreatment reduced CD86 mRNA level and increased CD206 mRNA level in spite of $A \beta$ treatment (Figures 2A,B). Immunostaining data showed a decrease in CD86 expression in $\mathrm{A} \beta$-exposed microglia with Acrp30 pretreatment (Figure 2C).

\section{The Activation and Polarization of Microglia in AD Mouse Brain}

To examine the changes of adiponectin receptors in microglia under $A \beta$ toxicity, we conducted reverse transcriptional PCR (Figures 3A,B) and western blotting (Figures 3C,D). The mRNA levels (Figures 3A,B) and protein levels (Figures 3C,D) of AdipoR1 and AdipoR2 were reduced in A $\beta$-treated microglia. Acrp30 promoted the expression of AdipoR1, whereas Acrp30 did not meaningfully change the expression of AdipoR2, in $\mathrm{A} \beta$-treated microglia (Figures $\mathbf{3 A}, \mathbf{B}$ ). Notably, the protein level of AdipoR1 in microglia was decreased by $A \beta$ treatment (Figure 3C).

\section{Acrp30 Treatment Leads to the Reduced Expression of Pro-Inflammatory Mediators in A $\beta$-Exposed Microglia}

To examine alterations in the expression of pro-inflammatory mediators by Acrp30, we assessed the production of $\mathrm{NO}$ using the Griess assay (Figure 4A) and the mRNA of iNOS (Figure 4B). Moreover, we detected the mRNA level of IL-6 and TNF- $\alpha$ as pro-inflammatory cytokines using real time PCR in microglia (Figures 4C,D). Acrp30 treatment did not change the level of NO, iNOS, IL-6, or TNF- $\alpha$ in BV2 microglia, whereas the expression of these pro-inflammatory mediators were increased in $A \beta$-treated microglia. Acrp30 pretreatment led to a decrease in NO, iNOS, IL- 6 and TNF- $\alpha$ in A $\beta$-treated microglia (Figures 4A-D).

\section{Acrp30 Reduced the Expression of TNF- $\alpha$ and iNOS in A $\beta$-Exposed Microglia}

To test for the expression of TNF- $\alpha$ and iNOS in A $\beta$-exposed microglia, we detected mRNA levels using reverse transcription PCR (Figure 5). The mRNA level of TNF- $\alpha$ in microglia under $\mathrm{A} \beta$ toxicity was significantly increased, while the mRNA level of TNF- $\alpha$ in $A \beta$-treated microglia was considerably reduced by Acrp30 pretreatment (Figure 5A). When we inhibited the expression of AdipoR1 using siRNA AdipoR1, we observed an increase in TNF- $\alpha$ mRNA level in $A \beta$-exposed microglia in spite of Acrp30 pretreatment (Figure 5A). In addition, the mRNA levels of iNOS and TNF- $\alpha$ showed the same expression patterns 


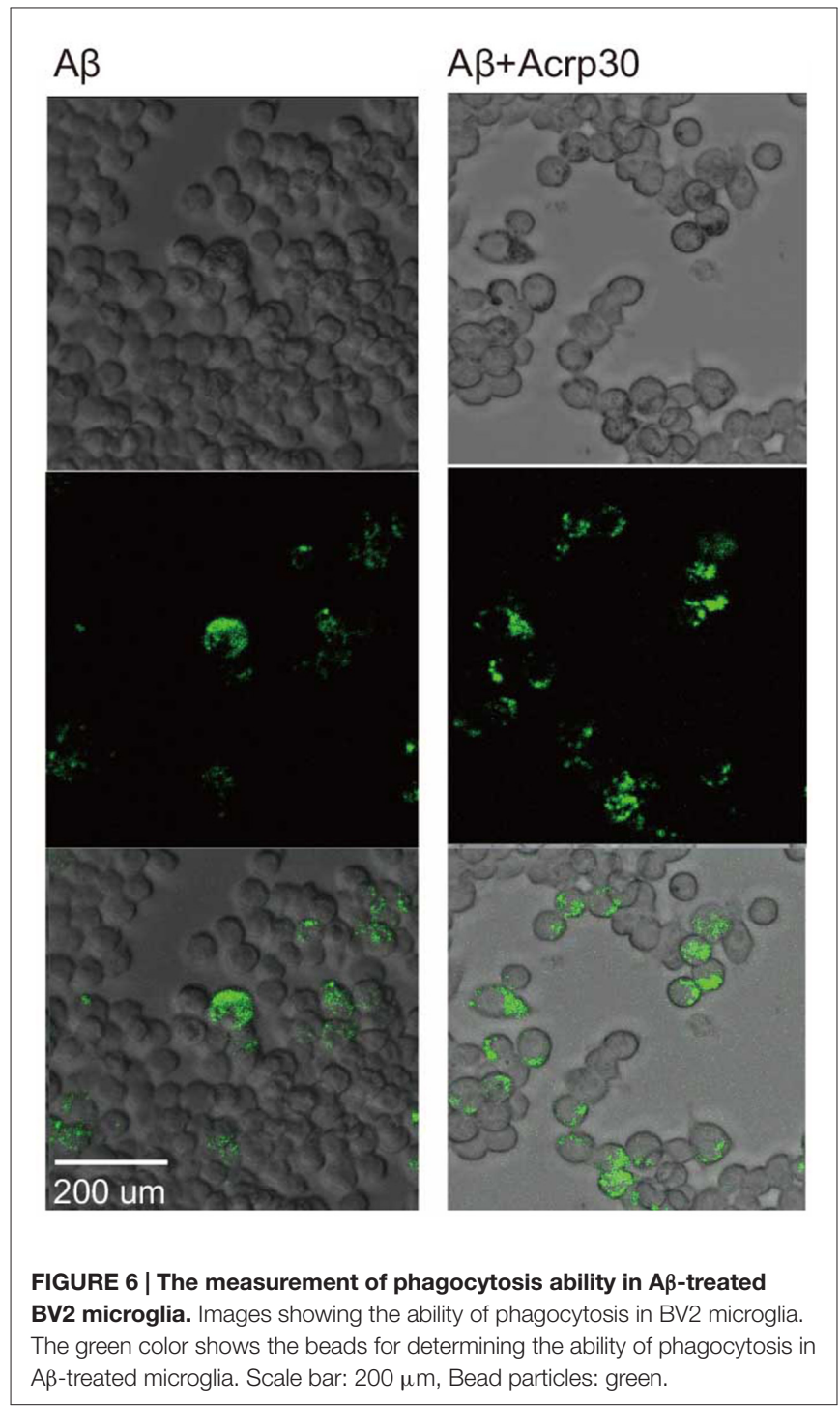

(Figure 5B), and the secretion of TNF- $\alpha$ and TNF- $\alpha$ mRNA level demonstrated similar patterns (Figure 5C). The knockdown of AdipoR1 did not reduce the expression of pro-inflammatory mediators (Figure 5).

\section{Acrp30 Increases the Ability of Phagocytosis in A $\beta$ Exposed Microglia}

To examine the phagocytotic ability of microglia, we conducted the phagocytosis assay (Figure 6). A $\beta$-exposed microglia showed that the green beads were phagocytosed in many microglia. Acrp30 were increased the phagocytosis ability of microglia in $A \beta$ toxicity (Figure 6). Thus, adiponectin promoted the phagocytosis ability of microglia in $\mathrm{A} \beta$ toxicity.

\section{Acrp30 Controls PPAR- $\gamma$ Signaling in A $\beta$ Exposed Microglia}

To examine whether Acrp30 influences the expression of PPAR- $\gamma$ in A $\beta$-treated microglia, we conducted real time PCR (Figure 7). The mRNA level of CD36 (a scavenger receptor for

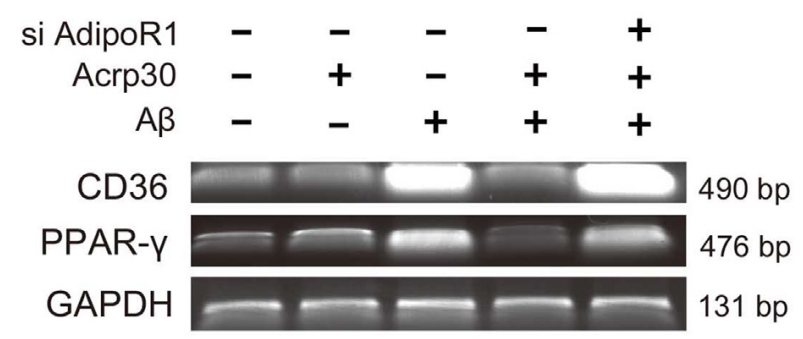

A
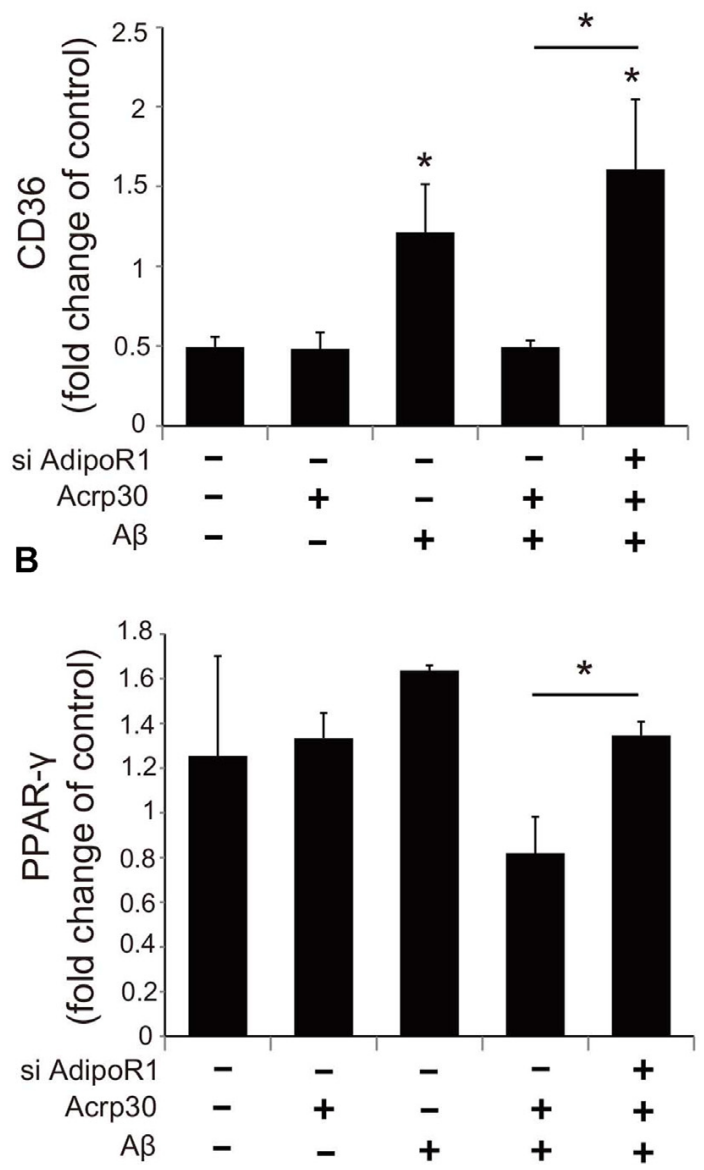

FIGURE 7 | The expression of CD36 and PPAR- $\gamma$ in A $\beta$ treated BV2 microglia. The mRNA levels of CD36 (A) and PPAR- $\gamma$ (B) were checked by RT PCR. The reduced mRNA levels of CD36 and PPAR- $\gamma$ by Acrp30 in A $\beta$ treated microglia were increased by inhibiting AdipoR1. Data are expressed as mean \pm SEM. Each experiment was conducted four times per condition. GAPDH served as a control. Differences were considered statistically significant at ${ }^{*} p<0.05$ (compared to control). Acrp30: Acrp30 $5 \mu \mathrm{g} / \mathrm{ml}$ pretreatment, $A \beta$ : $A \beta 10 \mu \mathrm{M}$ treatment for $24 \mathrm{~h}$, siAdipoR1: siRNA AdipoR1 transfection.

phagocytosis) was markedly increased in $A \beta$-treated microglia (Figure 7A). Acrp30 attenuated the expression of CD36 in microglia under $A \beta$ toxicity (Figure 7A). The mRNA level of PPAR- $\gamma$ was increased in A $\beta$ treated microglia, while Acrp30 reduced the expression of PPAR- $\gamma$ in microglia under $\mathrm{A} \beta$ toxicity (Figure 7B). To test whether Acrp30 directly 


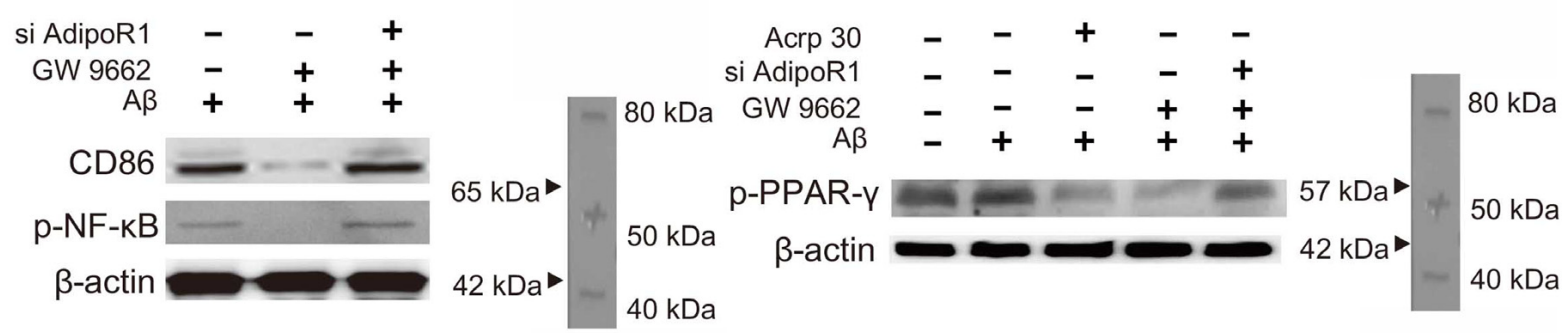

A

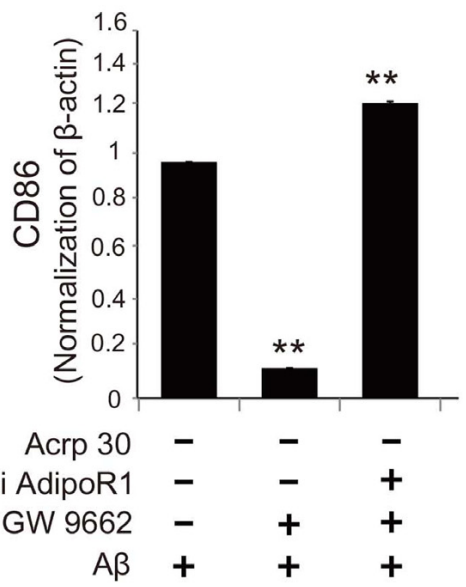

B

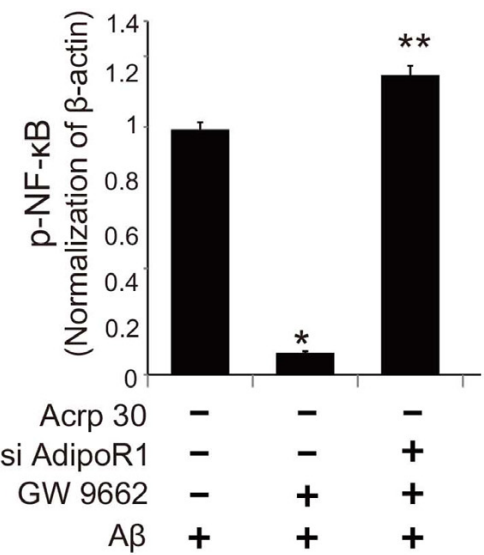

C

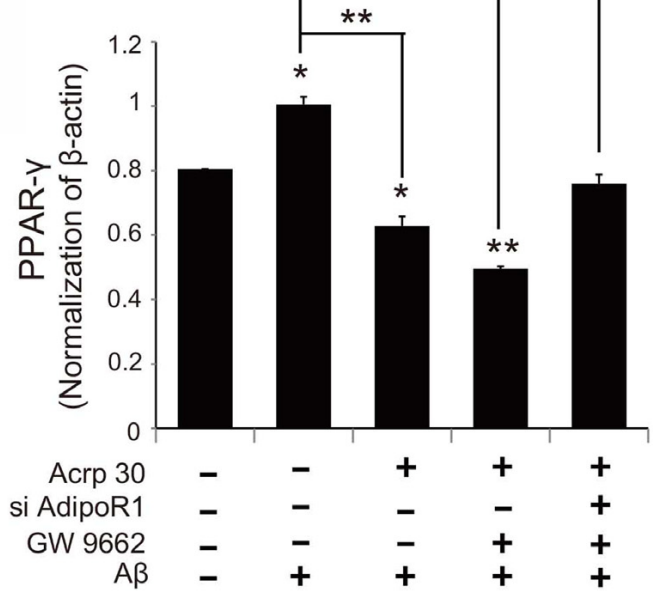

FIGURE 8 | The change in PPAR- $\boldsymbol{\gamma}$ signaling by inhibiting AdipoR1 in A $\boldsymbol{\beta}$-treated BV2 microglia. The protein levels of CD86 (A) and $p-N F-\kappa B$ (B) $p-P P A R-\gamma$ (C) protein were detected by western blotting analysis. (C) The decreased p-PPAR- $\gamma$ protein level by Acrp30 and GW9662 in A $\beta$-treated microglia was not changed by suppressing AdipoR1. Data are expressed as mean \pm SEM. Each experiment was conducted four times per condition. GAPDH served as a control. Differences were considered statistically significant at ${ }^{*} p<0.05$ (compared to control). Acrp30: Acrp30 $5 \mu \mathrm{g} / \mathrm{ml}$ pretreatment, $\mathrm{A} \beta$ : A $\beta$ 10 $\mu \mathrm{M}$ treatment for $24 \mathrm{~h}$, siAdipoR1: siRNA AdipoR1 transfection, GW9662: PPAR- $\gamma$ antagonist $10 \mu \mathrm{M} .{ }^{* *} p<0.001$.

regulates the PPAR- $\gamma$ signaling in $A \beta$ treated microglia, we examined CD86, p- NF- $\kappa$ B and PPAR- $\gamma$ protein levels using western blotting analysis (Figure 8) and tested the effect of the PPAR- $\gamma$ antagonist GW9662 in A $\beta$-treated microglia (Figure 8). Our results showed that GW9662 reduces the protein level of CD86 in spite of A $\beta$-treatment (Figure 8A). Reduced
CD86 protein level in A $\beta$ treated microglia with GW9662 was increased by inhibiting AdipoR1 (Figure 8A). The blocking of AdipoR1 reduced the function of PPAR- $\gamma$ (decreased the expression of CD86) in $\mathrm{A} \beta$-treated microglia (Figure 8A). In addition, GW9662 reduced the phosphorylation of NF- $\mathrm{B}$ in spite of $A \beta$-treatment (Figure $\mathbf{8 B}$ ). Reduced protein level of $\mathrm{p}$ - 
NF- $\kappa B$ in A $\beta$-treated microglia with GW9662 was increased by inhibiting AdipoR1 (Figure 8B). The protein level of PPAR- $\gamma$ in A $\beta$-treated microglia was reduced by Acrp30 and GW 9662, whereas the protein level of PPAR- $\gamma$ in A $\beta$-treated microglia with GW9662 was not changed by inhibition of AdipoR1 (Figure 8C). Based on our results, Acrp30 attenuated PPAR- $\gamma$ signaling in microglia by mediating AdipoR1.

\section{DISCUSSION}

$\mathrm{AD}$ is characterized by the abnormal accumulation of $\mathrm{A} \beta$ and chronic neuroinflammation (Ramanathan et al., 2015; Scheltens et al., 2016). Clearance of $A \beta$ and chronic inflammation are related to the polarization of and phagocytotic ability of microglia (Ide et al., 1996; Heese et al., 1998; Hutchinson et al., 2009; Tang and Le, 2016). The M2 phenotype microglia have been demonstrated to have a neuroprotective function in $\mathrm{AD}$ ( $\mathrm{Zhu}$ et al., 2016). A recent study showed that M2 macrophage transplantation reduces neuroinflammation in the brain, promotes clearance of $A \beta$, and improves cognitive impairment (Zhu et al., 2016). A $\beta$ and tau oligomers activate M1 pro-inflammatory responses and induce irreversible neuron loss (Tang and Le, 2016). The M1 phenotype microglia secrete pro-inflammatory mediators including TNF- $\alpha$, IL- 6 and NO, whereas anti-inflammatory M2 phenotype microglia produce anti-inflammatory mediators such as IL-10 and IL-4 under oxidative stress conditions (Tang and Le, 2016). In this study, we examined the alteration of cytokine expression by Acrp30 in $\mathrm{A} \beta$-treated microglia. We found that adiponectin attenuates the expression of pro-inflammatory cytokines, and AdipoR1 may mediate the function of adiponectin secretion of inflammatory cytokines, considering that the expression of pro-inflammatory cytokines was not reduced in $\mathrm{A} \beta$-treated microglia despite Acrp30 pretreatment.

In the present study, we found activated microglia in vivo in the $\mathrm{AD}$ mouse brain and in vitro under $\mathrm{A} \beta$-induced inflammatory conditions. Increased expression of CD86, a known M1 receptor marker (Gong et al., 2016) was found in the cortex and striatum of $5 \times \mathrm{FAD}$ mice, and in $\mathrm{A} \beta$-treated BV2 microglia. Based on our results, we suggest that adiponectin might promote the polarization of M2 type microglia under $A \beta$ toxicity conditions. Moreover, our results showed that adiponectin activates M2 phenotype microglia (Lovren et al., 2010). Increased CD206 and reduced M1 polarization was demonstrated by the reduction of pro-inflammatory cytokines such as TNF- $\alpha$ and IL-6, and the reduction of CD86 and iNOS expression.

Adiponectin regulates many processes by binding with specific receptors, AdipoR1 and AdipoR2 (Hug et al., 2004) and exists in various organs, including the brain (Kaminski et al., 2014). We observed more expression of AdipoR1 than AdipoR2 in BV2 microglia under A $\beta$ induced toxicity. Previous studies demonstrated that downregulation of AdipoR1 attenuates anti-inflammatory responses (Zhang et al., 2016) and reduces the adiponectin's beneficial actions in macrophages (Luo et al., 2013). We observed that the downregulation of AdipoR1 by siRNA AdipoR1 increases pro-inflammatory cytokines including TNF- $\alpha$ and iNOS production under $A \beta$ toxicity in spite of Acrp30 pretreatment. Judging from our results, we assume that the inhibitory effect of adiponectin in pro-inflammatory cytokine production may be mediated by AdipoR1.

Fibrillar $A \beta$ has been reported to interact with the cell surface receptor and leads to intracellular signaling, and then stimulates phagocytosis (D'Andrea et al., 2004; Mohamed and Posse de Chaves, 2011). CD36, one of the class B scavenger receptors, has been shown to be expressed in various cell types and bind with diverse ligands (Febbraio et al., 2001), and to participate in the internalization of numerous small particles, including $\mathrm{A} \beta$ (Koenigsknecht and Landreth, 2004) and apoptotic cells (Fadok et al., 1998). CD36 has been shown to uptake $A \beta$ (Moore et al., 2002), and is involved in the production of pro-inflammatory mediators (Janabi et al., 2000; Stuart et al., 2005; Baranova et al., 2008). Several studies have demonstrated that CD36 boosts pro-inflammatory responses (Janabi et al., 2000; Moore et al., 2002; Okamura et al., 2009; Silverstein and Febbraio, 2009) and phagocytosis (Erdman et al., 2009). Studies have also shown that the activation of macrophages promotes the expression of CD36 by generation of ligands of PPAR- $\gamma$ (Huang et al., 1999; Berry et al., 2007) and adiponectin inhibits the expression of scavenger receptor CD36 (Ouchi et al., 2001). Based on the current results, we hypothesize that adiponectin can attenuate the expression of $\mathrm{CD} 36$, leading to the production of pro-inflammatory cytokines.

Moreover, previous studies have demonstrated that PPAR- $\gamma$ can mediate the conversion of the microglia phenotype (Yamanaka et al., 2012; Saijo et al., 2013). Our results indicate that PPAR- $\gamma$ may induce M2 phenotype microglia under $A \beta$ toxicity via adiponectin treatment. Several studies have demonstrated that PPAR- $\gamma$ agonists alleviate neuroinflammation in $\mathrm{AD}$ models by acting as anti-inflammatory regulators (Ghisletti et al., 2007; Saijo et al., 2013) while others have shown that PPAR- $\gamma$ can regulate the secretion of inflammatory cytokines in microglia, ultimately promoting tissue repair (Chawla, 2010; Chinetti-Gbaguidi et al., 2011).

In the present study, we found that adiponectin may contribute to the function and polarization of microglia through PPAR- $\gamma$ signaling. In particular, adiponectin may play a proinflammatory role through PPAR- $\gamma$ by mediating AdipoR1. Even though we did not present evidence on memory improvement by adiponectin through PPAR $-\gamma$ in AD brain, we speculate that adiponectin may improve memory in $\mathrm{AD}$ by attenuating PPAR- $\gamma$ signaling in microglia, and regulate the function of microglia under $A \beta$ toxicity by regulating PPAR- $\gamma$ through AdipoR1.

Taken together, we conclude that: (1) adiponectin may induce the $\mathrm{M} 2$ polarization of microglia in $\mathrm{A} \beta$ toxicity; (2) adiponectin may regulate the production of pro-inflammatory cytokines by mediating AdipoR1 under $\mathrm{A} \beta$ toxicity; and (3) adiponectin may exert anti-inflammatory functions in microglia and regulate the polarization of microglia through PPAR- $\gamma$ signaling under $\mathrm{A} \beta$ toxicity. Thus, we suggest that adiponectin is a crucial adipokine to attenuate $\mathrm{AD}$ pathology by regulating the function of microglia. 


\section{AUTHOR CONTRIBUTIONS}

JS conducted the experiments and contributed to the writing of the preliminary draft. S-MC conducted the experiments. BCK designed the study and wrote the manuscript, and provided overall supervision for the project.

\section{REFERENCES}

An, K., Klyubin, I., Kim, Y., Jung, J. H., Mably, A. J., O’Dowd, S. T., et al. (2013). Exosomes neutralize synaptic-plasticity-disrupting activity of $\mathrm{A} \beta$ assemblies in vivo. Mol. Brain 6:47. doi: 10.1186/1756-6606-6-47

Baranova, I. N., Kurlander, R., Bocharov, A. V., Vishnyakova, T. G., Chen, Z., Remaley, A. T., et al. (2008). Role of human CD36 in bacterial recognition, phagocytosis and pathogen-induced JNK-mediated signaling. J. Immunol. 181, 7147-7156. doi: 10.4049/jimmunol.181.10.7147

Beletskii, A., Cooper, M., Sriraman, P., Chiriac, C., Zhao, L., Abbot, S., et al. (2005). High-throughput phagocytosis assay utilizing a $\mathrm{pH}$-sensitive fluorescent dye. Biotechniques 39, 894-897. doi: 10.2144/000112001

Berry, A., Balard, P., Coste, A., Olagnier, D., Lagane, C., Authier, H., et al. (2007). IL-13 induces expression of CD36 in human monocytes through PPAR $\gamma$ activation. Eur. J. Immunol. 37, 1642-1652. doi: 10.1002/eji.200 636625

Bubu, O. M., Brannick, M., Mortimer, J., Umasabor-Bubu, O., Sebastião, Y. V., Wen, Y., et al. (2016). Sleep, cognitive impairment and Alzheimer's disease: a systematic review and meta-analysis. Sleep doi: 10.1093/sleep/zsw032 [Epub ahead of print].

Chawla, A. (2010). Control of macrophage activation and function by PPARs. Circ. Res. 106, 1559-1569. doi: 10.1161/CIRCRESAHA.110.216523

Chen, M., Li, H., Wang, G., Shen, X., Zhao, S., and Su, W. (2016). Atorvastatin prevents advanced glycation end products (AGEs)-induced cardiac fibrosis via activating peroxisome proliferator-activated receptor gamma (PPAR- $\gamma$ ). Metabolism 65, 441-453. doi: 10.1016/j.metabol.2015.11.007

Chinetti-Gbaguidi, G., Baron, M., Bouhlel, M. A., Vanhoutte, J., Copin, C., Sebti, Y., et al. (2011). Human atherosclerotic plaque alternative macrophages display low cholesterol handling but high phagocytosis because of distinct activities of the PPAR $\gamma$ and LXR $\alpha$ pathways. Circ. Res. 108, 985-995. doi: 10.1161/CIRCRESAHA.110.233775

Combs, C. K., Karlo, J. C., Kao, S. C., and Landreth, G. E. (2001). $\beta$-Amyloid stimulation of microglia and monocytes results in TNF $\alpha$-dependent expression of inducible nitric oxide synthase and neuronal apoptosis. J. Neurosci. 21, 1179-1188.

D'Andrea, M. R., Cole, G. M., and Ard, M. D. (2004). The microglial phagocytic role with specific plaque types in the Alzheimer disease brain. Neurobiol. Aging 25, 675-683. doi: 10.1016/j.neurobiolaging.2003.12.026

Del Bo, R., Angeretti, N., Lucca, E., De Simoni, M. G., and Forloni, G. (1995). Reciprocal control of inflammatory cytokines, IL-1 and IL- 6 and $\beta$-amyloid production in cultures. Neurosci. Lett. 188, 70-74. doi: 10.1016/03043940(95)11384-9

De Strooper, B., and Karran, E. (2016). The cellular phase of Alzheimer's disease. Cell 164, 603-615. doi: 10.1016/j.cell.2015.12.056

Doens, D., and Fernández, P. L. (2014). Microglia receptors and their implications in the response to amyloid $\beta$ for Alzheimer's disease pathogenesis. J. Neuroinflammation 11:48. doi: 10.1186/1742-2094-11-48

Eggen, B. J. L., Raj, D., Hanisch, U.-K., and Boddeke, H. W. G. (2013). Microglial phenotype and adaptation. J. Neuroimmune Pharmacol. 8, 807-823. doi: 10.1007/s11481-013-9490-4

Elfeky, M., Kaede, R., Okamatsu-Ogura, Y., and Kimura, K. (2016). Adiponectin inhibits LPS-induced HMGB1 release through an AMP kinase and heme oxygenase-1-dependent pathway in RAW 264 macrophage cells. Mediators Inflamm. 2016:5701959. doi: 10.1155/2016/5701959

Erdman, L. K., Cosio, G., Helmers, A. J., Gowda, D. C., Grinstein, S., and Kain, K. C. (2009). CD36 and TLR interactions in inflammation and phagocytosis: implications for malaria. J. Immunol. 183, 6452-6459. doi: 10.4049/jimmunol.0901374

\section{ACKNOWLEDGMENTS}

This study was supported by the Brain Research Program through the National Research Foundation of Korea funded by the Ministry of Science, ICT and Future Planning NRF-2016M3C7A1905469 (BCK) and a grant from 2016R1D1A1B03930394 (JS).

Fadok, V. A., Warner, M. L., Bratton, D. L., and Henson, P. M. (1998). CD36 is required for phagocytosis of apoptotic cells by human macrophages that use either a phosphatidylserine receptor or the vitronectin receptor $\left(\alpha_{\mathrm{v}} \beta_{3}\right)$. I. Immunol. 161, 6250-6257.

Febbraio, M., Hajjar, D. P., and Silverstein, R. L. (2001). CD36: a class B scavenger receptor involved in angiogenesis, atherosclerosis, inflammation and lipid metabolism. J. Clin. Invest. 108, 785-791. doi: 10.1172/ JCI14006

Francos-Quijorna, I., Amo-Aparicio, J., Martinez-Muriana, A., and LópezVales, R. (2016). IL-4 drives microglia and macrophages toward a phenotype conducive for tissue repair and functional recovery after spinal cord injury. Glia 64, 2079-2092. doi: 10.1002/glia.23041

Gertig, U., and Hanisch, U. K. (2014). Microglial diversity by responses and responders. Front. Cell. Neurosci. 8:101. doi: 10.3389/fncel.2014 00101

Ghisletti, S., Huang, W., Ogawa, S., Pascual, G., Lin, M. E., Willson, T. M., et al. (2007). Parallel SUMOylation-dependent pathways mediate gene- and signalspecific transrepression by LXRs and PPAR $\gamma$. Mol. cell 25, 57-70. doi: 10.1016/j. molcel.2006.11.022

Ginhoux, F., and Prinz, M. (2015). Origin of microglia: current concepts and past controversies. Cold Spring Harb. Perspect. Biol. 7:a020537. doi: 10.1101/cshperspect.a020537

Goate, A. (2006). Segregation of a missense mutation in the amyloid $\beta$-protein precursor gene with familial Alzheimer's disease. J. Alzheimers Dis. 9, 341-347. doi: 10.1007/978-3-540-37652-1_16

Gong, L., Wang, H., Sun, X., Liu, C., Duan, C., Cai, R., et al. (2016). TollInterleukin 1 Receptor domain-containing adaptor protein positively regulates BV2 cell M1 polarization. Eur. J. Neurosci. 43, 1674-1682. doi: 10.1111/ejn. 13257

Hardy, J., Bogdanovic, N., Winblad, B., Portelius, E., Andreasen, N., CedazoMinguez, A., et al. (2014). Pathways to Alzheimer's disease. J. Intern. Med. 275, 296-303. doi: 10.1111/joim.12192

Hardy, J., and Selkoe, D. J. (2002). The amyloid hypothesis of Alzheimer's disease: progress and problems on the road to therapeutics. Science 297, 353-356. doi: $10.1126 /$ science. 1072994

Heese, K., Hock, C., and Otten, U. (1998). Inflammatory signals induce neurotrophin expression in human microglial cells. J. Neurochem. 70, 699-707. doi: 10.1046/j.1471-4159.1998.70020699.x

Huang, J. T., Welch, J. S., Ricote, M., Binder, C. J., Willson, T. M., Kelly, C., et al. (1999). Interleukin-4-dependent production of PPAR- $\gamma$ ligands in macrophages by 12/15-lipoxygenase. Nature 400, 378-382. doi: 10.1038/22572

Hug, C., Wang, J., Ahmad, N. S., Bogan, J. S., Tsao, T.-S., and Lodish, H. F. (2004). T-cadherin is a receptor for hexameric and high-molecular-weight forms of Acrp30/adiponectin. Proc. Natl. Acad. Sci. U S A 101, 10308-10313. doi: $10.1073 /$ pnas. 0403382101

Hutchinson, A. J., Chou, C. L., Israel, D. D., Xu, W., and Regan, J. W. (2009) Activation of EP2 prostanoid receptors in human glial cell lines stimulates the secretion of BDNF. Neurochem. Int. 54, 439-446. doi: 10.1016/j.neuint.2009. 01.018

Ide, C. F., Scripter, J. L., Coltman, B. W., Dotson, R. S., Snyder, D. C., and Jelaso, A. (1996). Cellular and molecular correlates to plasticity during recovery from injury in the developing mammalian brain. Prog. Brain Res. 108, 365-377. doi: 10.1016/s0079-6123(08)62552-2

Janabi, M., Yamashita, S., Hirano, K., Sakai, N., Hiraoka, H., Matsumoto, K., et al. (2000). Oxidized LDL-induced NF-кB activation and subsequent expression of proinflammatory genes are defective in monocyte-derived macrophages from CD36-deficient patients. Arterioscler. Thromb. Vasc. Biol. 20, 1953-1960. doi: 10.1161/01.atv.20.8.1953 
Kadowaki, T., Yamauchi, T., Kubota, N., Hara, K., Ueki, K., and Tobe, K. (2006). Adiponectin and adiponectin receptors in insulin resistance, diabetes, and the metabolic syndrome. J. Clin. Invest. 116, 1784-1792. doi: 10.1172/jci 29126

Kaminski, T., Smolinska, N., Maleszka, A., Kiezun, M., Dobrzyn, K., Czerwinska, J., et al. (2014). Expression of adiponectin and its receptors in the porcine hypothalamus during the oestrous cycle. Reprod. Domest. Anim. 49, 378-386. doi: 10.1111/rda.12282

Kempuraj, D., Thangavel, R., Natteru, P. A., Selvakumar, G. P., Saeed, D., Zahoor, H., et al. (2016). Neuroinflammation induces neurodegeneration. J. Neurol. Neurosurg. Spine 1.

Kim, J., Zheng, W., Grafer, C., Mann, M. L., and Halvorson, L. M. (2013). GnRH decreases adiponectin expression in pituitary gonadotropes via the calcium and PKA pathways. Reprod. Sci. 20, 937-945. doi: 10.1177/19337191124 68947

Koenigsknecht, J., and Landreth, G. (2004). Microglial phagocytosis of fibrillar $\beta$-amyloid through a $\beta_{1}$ integrin-dependent mechanism. J. Neurosci. 24, 9838-9846. doi: 10.1523/JNEUROSCI.2557-04.2004

Latta, C. H., Sudduth, T. L., Weekman, E. M., Brothers, H. M., Abner, E. L., Popa, G. J., et al. (2015). Determining the role of IL-4 induced neuroinflammation in microglial activity and amyloid- $\beta$ using BV2 microglial cells and APP/PS1 transgenic mice. J. Neuroinflammation 12:41. doi: 10.1186/s12974-015-0243-6

Lee, J. H., Wei, Z. Z., Cao, W., Won, S., Gu, X., Winter, M., et al. (2016). Regulation of therapeutic hypothermia on inflammatory cytokines, microglia polarization, migration and functional recovery after ischemic stroke in mice. Neurobiol. Dis. 96, 248-260. doi: 10.1016/j.nbd.2016.09.013

Lindberg, C., Selenica, M. L., Westlind-Danielsson, A., and Schultzberg, M. (2005). $\beta$-amyloid protein structure determines the nature of cytokine release from rat microglia. J. Mol. Neurosci. 27, 1-12. doi: 10.1385/jmn:27:1:001

Lovren, F., Pan, Y., Quan, A., Szmitko, P. E., Singh, K. K., Shukla, P. C., et al. (2010). Adiponectin primes human monocytes into alternative anti-inflammatory M2 macrophages. Am. J. Physiol. Heart Circ. Physiol. 299, H656-H663. doi: 10.1152/ajpheart.00115.2010

Luo, N., Chung, B. H., Wang, X., Klein, R. L., Tang, C. K., Garvey, W. T., et al. (2013). Enhanced adiponectin actions by overexpression of adiponectin receptor 1 in macrophages. Atherosclerosis 228, 124-135. doi: 10.1016/j. atherosclerosis.2013.02.026

Maeda, K., Okubo, K., Shimomura, I., Funahashi, T., Matsuzawa, Y., and Matsubara, K. (1996). cDNA cloning and expression of a novel adipose specific collagen-like factor, apM1 (AdiPose Most abundant Gene transcript 1). Biochem. Biophys. Res. Commun. 221, 286-289. doi: 10.1006/bbrc.1996.0587

Masamoto, Y., Arai, S., Sato, T., Yoshimi, A., Kubota, N., Takamoto, I., et al. (2016). Adiponectin enhances antibacterial activity of hematopoietic cells by suppressing bone marrow inflammation. Immunity 44, 1422-1433. doi: 10.1016/j.immuni.2016.05.010

Mehlhorn, G., Hollborn, M., and Schliebs, R. (2000). Induction of cytokines in glial cells surrounding cortical $\beta$-amyloid plaques in transgenic Tg2576 mice with Alzheimer pathology. Int. J. Dev. Neurosci. 18, 423-431. doi: 10.1016/s07365748(00)00012-5

Mohamed, A., and Posse de Chaves, E. (2011). A $\beta$ internalization by neurons and glia. Int. J. Alzheimers Dis. 2011:127984. doi: 10.4061/2011/127984

Moore, K. J., El Khoury, J., Medeiros, L. A., Terada, K., Geula, C., Luster, A. D., et al. (2002). A CD36-initiated signaling cascade mediates inflammatory effects of $\beta$-amyloid. J. Biol. Chem. 277, 47373-47379. doi: 10.1074/jbc.M208788200

Nakamichi, Y., Udagawa, N., and Takahashi, N. (2013). IL-34 and CSF-1: similarities and differences. J. Bone Miner. Metab. 31, 486-495. doi: 10.1007/s00774-013-0476-3

Natoli, G., and Monticelli, S. (2014). Macrophage activation: glancing into diversity. Immunity 40, 175-177. doi: 10.1016/j.immuni.2014.01.004

Okamura, D. M., Pennathur, S., Pasichnyk, K., López-Guisa, J. M., Collins, S., Febbraio, M., et al. (2009). CD36 regulates oxidative stress and inflammation in hypercholesterolemic CKD. J. Am. Soc. Nephrol. 20, 495-505. doi: 10.1681/ASN.2008010009

Ouchi, N., Kihara, S., Arita, Y., Nishida, M., Matsuyama, A., Okamoto, Y., et al. (2001). Adipocyte-derived plasma protein, adiponectin, suppresses lipid accumulation and class A scavenger receptor expression in human monocytederived macrophages. Circulation 103, 1057-1063. doi: 10.1161/01.cir.103. 8.1057
Parkhurst, C. N., Yang, G., Ninan, I., Savas, J. N., Yates, J. R. III, Lafaille, J. J., et al. (2013). Microglia promote learning-dependent synapse formation through brain-derived neurotrophic factor. Cell 155, 1596-1609. doi: 10.1016/j.cell. 2013.11.030

Plastira, I., Bernhart, E., Goeritzer, M., Reicher, H., Kumble, V. B., Kogelnik, N., et al. (2016). 1-Oleyl-lysophosphatidic acid (LPA) promotes polarization of BV-2 and primary murine microglia towards an M1-like phenotype. J. Neuroinflammation 13:205. doi: 10.1186/s12974-016-0701-9

Popivanova, B. K., Kitamura, K., Wu, Y., Kondo, T., Kagaya, T., Kaneko, S., et al. (2008). Blocking TNF- $\alpha$ in mice reduces colorectal carcinogenesis associated with chronic colitis. J. Clin. Invest. 118, 560-570. doi: 10.1172/JCI32453

Ramanathan, A., Nelson, A. R., Sagare, A. P., and Zlokovic, B. V. (2015). Impaired vascular-mediated clearance of brain amyloid beta in Alzheimer's disease: the role, regulation and restoration of LRP1. Front. Aging Neurosci. 7:136. doi: $10.3389 /$ fnagi.2015.00136

Renaldi, O., Pramono, B., Sinorita, H., Purnomo, L. B., Asdie, R. H., and Asdie, A. H. (2009). Hypoadiponectinemia: a risk factor for metabolic syndrome. Acta Med. Indones. 41, 20-24.

Rogers, J., and Lue, L. F. (2001). Microglial chemotaxis, activation and phagocytosis of amyloid $\beta$-peptide as linked phenomena in Alzheimer's disease. Neurochem. Int. 39, 333-340. doi: 10.1016/s0197-0186(01) 00040-7

Rogers, J., Strohmeyer, R., Kovelowski, C. J., and Li, R. (2002). Microglia and inflammatory mechanisms in the clearance of amyloid $\beta$ peptide. Glia 40, 260-269. doi: 10.1002/glia.10153

Saijo, K., Crotti, A., and Glass, C. K. (2013). Regulation of microglia activation and deactivation by nuclear receptors. Glia 61, 104-111. doi: 10.1002/glia.22423

Scheltens, P., Blennow, K., Breteler, M. M., de Strooper, B., Frisoni, G. B., Salloway, S., et al. (2016). Alzheimer's disease. Lancet 388, 505-517. doi: 10.1016/S0140-6736(15)01124-1

Silverstein, R. L., and Febbraio, M. (2009). CD36, a scavenger receptor involved in immunity, metabolism, angiogenesis and behavior. Sci. Signal. 2:re3. doi: 10.1126/scisignal.272re3

Solé-Domènech, S., Cruz, D. L., Capetillo-Zarate, E., and Maxfield, F. R. (2016). The endocytic pathway in microglia during health, aging and Alzheimer's disease. Ageing Res. Rev. 32, 89-103. doi: 10.1016/j.arr.2016.07.002

Stamouli, E. C., and Politis, A. M. (2016). Pro-inflammatory cytokines in Alzheimer's disease. Psychiatrike 27, 264-275. doi: 10.22365/jpsych.2016. 274.264

Stuart, L. M., Deng, J., Silver, J. M., Takahashi, K., Tseng, A. A., Hennessy, E. J., et al. (2005). Response to Staphylococcus aureus requires CD36-mediated phagocytosis triggered by the $\mathrm{COOH}$-terminal cytoplasmic domain. J. Cell Biol. 170, 477-485. doi: 10.1083/jcb.200501113

Takata, K., Kitamura, Y., Umeki, M., Tsuchiya, D., Kakimura, J., Taniguchi, T., et al. (2003). Possible involvement of small oligomers of amyloid- $\beta$ peptides in 15-deoxy- $\delta 12,14$ prostaglandin J2-sensitive microglial activation. J. Pharmacol. Sci. 91, 330-333. doi: 10.1254/jphs.91.330

Tang, Y., and Le, W. (2016). Differential Roles of M1 and M2 microglia in neurodegenerative diseases. Mol. Neurobiol. 53, 1181-1194. doi: 10.1007/s12035-014-9070-5

Tarantini, S., Tran, C. H., Gordon, G. R., Ungvari, Z., and Csiszar, A. (2016). Impaired neurovascular coupling in aging and Alzheimer's disease: contribution of astrocyte dysfunction and endothelial impairment to cognitive decline. Exp. Gerontol. doi: 10.1016/j.exger.2016.11.004 [Epub ahead of print].

Tremblay, M. Ė., Lecours, C., Samson, L., Sánchez-Zafra, V., and Sierra, A. (2015). From the Cajal alumni Achucarro and Rio-Hortega to the rediscovery of never-resting microglia. Front. Neuroanat. 9:45. doi: 10.3389/fnana.2015 00045

Tremblay, M. Ė., Stevens, B., Sierra, A., Wake, H., Bessis, A., and Nimmerjahn, A. (2011). The role of microglia in the healthy brain. J. Neurosci. 31, 16064-16069. doi: 10.1523/JNEUROSCI.4158-11.2011

Wang, X., Buechler, N. L., Yoza, B. K., McCall, C. E., and Vachharajani, V. (2016). Adiponectin treatment attenuates inflammatory response during early sepsis in obese mice. J. Inflamm. Res. 9, 167-174. doi: 10.2147/jir.s119021

Weekman, E. M., Sudduth, T. L., Abner, E. L., Popa, G. J., Mendenhall, M. D., Brothers, H. M., et al. (2014). Transition from an M1 to a mixed neuroinflammatory phenotype increases amyloid deposition in APP/PS1 transgenic mice. J. Neuroinflammation 11:127. doi: 10.1186/17422094-11-127 
Xu, X., Gao, Y., Wen, L., Zhai, Z., Zhang, S., Shan, F., et al. (2016). Methionine enkephalin regulates microglia polarization and function. Int. Immunopharmacol. 40, 90-97. doi: 10.1016/j.intimp.2016.08.037

Yamanaka, M., Ishikawa, T., Griep, A., Axt, D., Kummer, M. P., and Heneka, M. T. (2012). PPAR $\gamma / \mathrm{RXR} \alpha$-induced and CD36-mediated microglial amyloid- $\beta$ phagocytosis results in cognitive improvement in amyloid precursor protein/presenilin 1 mice. J. Neurosci. 32, 17321-17331. doi: 10.1523/JNEUROSCI.1569-12.2012

Yamauchi, T., Kamon, J., Ito, Y., Tsuchida, A., Yokomizo, T., Kita, S., et al. (2003). Cloning of adiponectin receptors that mediate antidiabetic metabolic effects. Nature 423, 762-769. doi: 10.1038/nature01705

Zhang, P., Huang, C., Li, J., Li, T., Guo, H., Liu, T., et al. (2016). Globular CTRP9 inhibits oxLDL-induced inflammatory response in RAW 264.7 macrophages via AMPK activation. Mol. Cell. Biochem. 417, 67-74. doi: $10.1007 /$ s11010-016-2714-1
Zhu, D., Yang, N., Liu, Y. Y., Zheng, J., Ji, C., and Zuo, P. P. (2016). M2 Macrophage transplantation ameliorates cognitive dysfunction in amyloid$\beta$-treated rats through regulation of microglial polarization. J. Alzheimers Dis. 52, 483-495. doi: 10.3233/JAD-151090

Conflict of Interest Statement: The authors declare that the research was conducted in the absence of any commercial or financial relationships that could be construed as a potential conflict of interest.

Copyright (c) 2017 Song, Choi and Kim. This is an open-access article distributed under the terms of the Creative Commons Attribution License (CC BY). The use, distribution and reproduction in other forums is permitted, provided the original author(s) or licensor are credited and that the original publication in this journal is cited, in accordance with accepted academic practice. No use, distribution or reproduction is permitted which does not comply with these terms. 